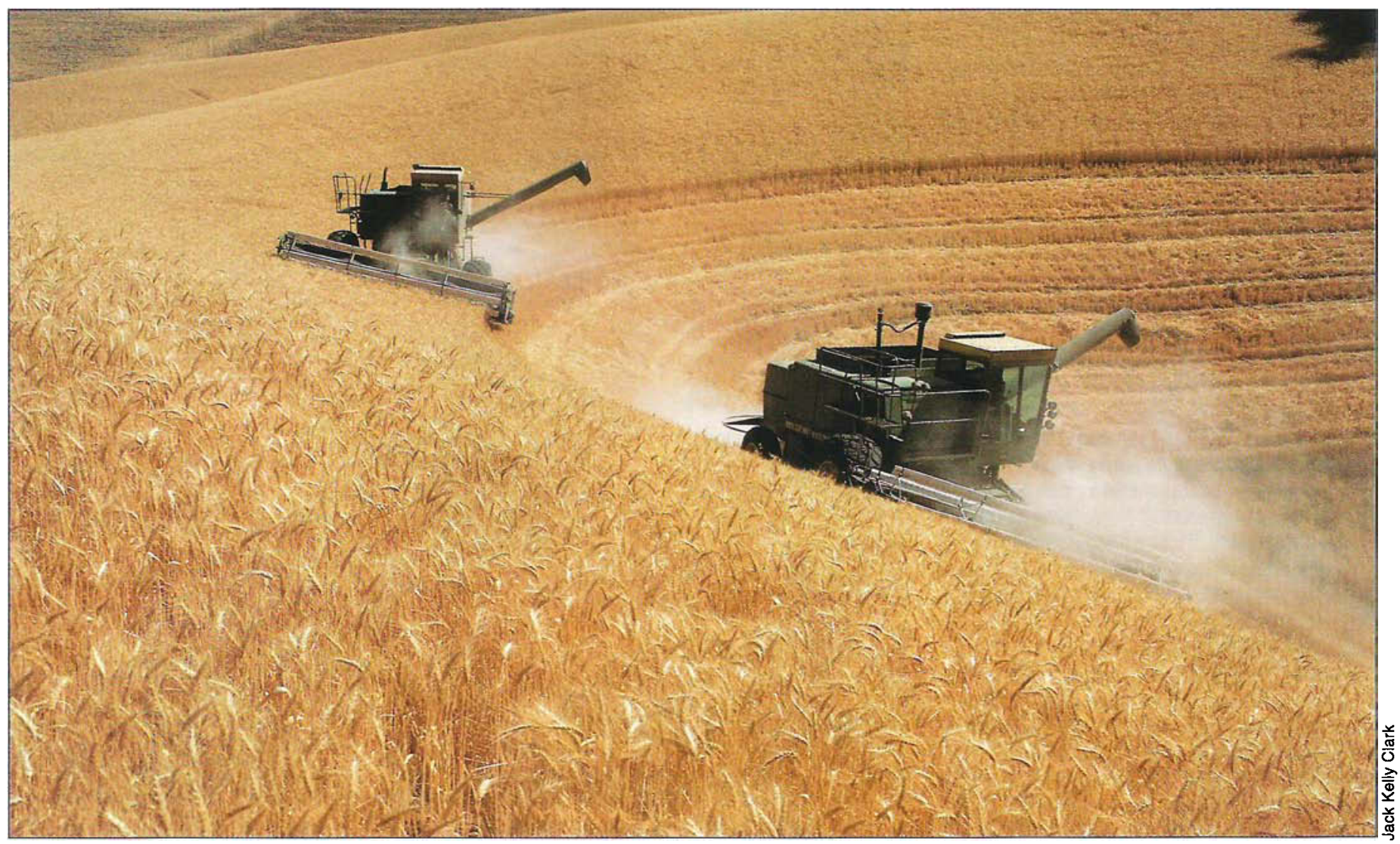

California cereal crops have suffered massive damage from Russian wheat aphid since 1988.

\title{
Natural enemies of Russian wheat aphid identified in California
}
J. Bernal
$\square$
D. González
口
E. T. Natwick
J. G. Loya
$\square$
R. León-Lopez
$\square$
W. E. Bendixen

\begin{abstract}
A survey of natural enemies of Russian wheat aphid conducted over several growing seasons reveals a complex of predators and parasites attacking this pest in California cereal fields. Because of environmental and economic considerations, unilateral use of insecticides is not a sound management strategy against this pest. A number of promising natural enemies have been imported and are now being reared for release in California cereal fields. These natural enemies may augment the effectiveness of those already present in California.
\end{abstract}

Since its detection in Texas in 1986, Russian wheat aphid [Diuraphis noxia (Mordwilko)] has become a major pest of small grains in 16 western states and has caused losses cumulatively exceeding $\$ 500$ million. First detected in California's Imperial County in 1988, the aphid did an estimated $\$ 8$ million of damage to the state's cereal crops in the 1988-1989 growing season.

The Russian wheat aphid was first recorded during the early 1900 s as a pest of cereals in areas along the Black Sea's northern coast (former USSR). Its native range is not clear, but recent findings suggest that it is native to the northwestern area of the People's Republic of China. This aphid was not recorded outside of the former USSR until 1938, when it was documented infesting cereals in Morocco.
Recommendations for managing the aphid, largely adopted from other countries where the pest is present, rely heavily on insecticide use. Management strategies being developed in California involve biological control and crop resistance because unilateral use of insecticides may not be economically, biologically or ecologically sound. Furthermore, extensive planting to small grains, with depressed market prices, makes chemical control too costly. The continued spread of this pest into new areas presents a serious obstacle to profitable small grains production in California.

Its exotic origin makes Russian wheat aphid an excellent target for biological control in the U.S. In areas of the world where this pest has long been present it is only an occasional pest, indicating that its natural enemies are effective 


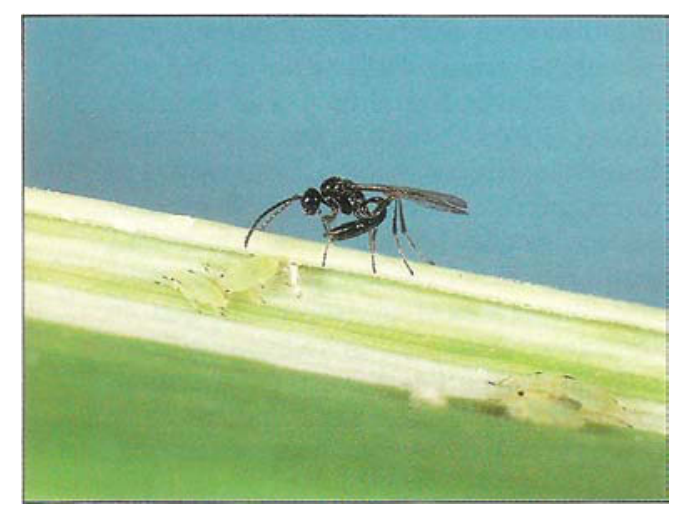

Parasitic wasp, Diaeretiella rapae, prepares to strike Russian wheat aphids.

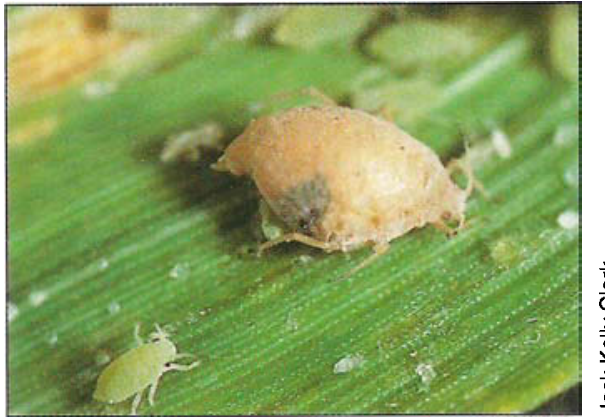

Russian wheat aphid mummy with adult parasite visible inside.

there. Hence, state and federal agencies in the U.S. have focused on importing natural enemies from those areas where the aphid is at sub-pest levels. Several of these natural enemies are being reared at the UC Riverside insectary for release in California. Upon their establishment, released natural enemies may augment the effectiveness of those already present in California.

Before the release and colonization of imported natural enemies, the extant natural enemies of Russian wheat aphid in California were surveyed. The survey's results should help verify and document the establishment and impact of the imported natural enemies when released in California. Initial field obsėrvations during 1989 in six California localities (El Centro, Lancaster, Lucerne Valley, Manteca, Parlier and Riverside), and the Mexicali Valley in Mexico revealed that a complex of at least two indigenous species of parasites and six species of predators were attacking Russian wheat aphid. Observations during 1990, 1991 and 1992 added several natural enemies and some hyperparasite species (parasites of parasites, which may thus be considered detrimental to biological control) to the known complex.

Here, we report our findings from a survey of natural enemies of Russian wheat aphid conducted during the 19891992 cereal-growing seasons in several southern and central California localities and Mexico.

\section{Aphid biology, crop damage}

Russian wheat aphid infestations begin as small colonies in early spring, shortly after the emergence of small grains. Initially, the colonies begin feeding within the axils of the expanding leaves, causing the leaves to curl and \% provide shelter in which they can grow. This protected habitat enables the aphids to survive and reproduce in extreme heat and cold. As the host plant matures and leaves are damaged, the colonies migrate to new leaves, eventually colonizing the upper leaves and heads.

Physiological changes in the host plant, together with crowded and adverse environmental conditions, eventually render the host plant unsuitable for further feeding. This triggers the production of winged progeny in the aphid colony. Winged adult aphids then miorate to suitable hosts and begin new colonies. In the absence of suitable wheat hosts, winged females migrate to $\sim$ alternate hosts that include more than 140 species of grasses. From there, Russian wheat aphids re-infest wheat crops as they become available the following season.

Feeding by Russian wheat aphid from plant emergence to the head stage can directly reduce the host crop's yield. While feeding, the aphid injects a toxin that destroys chloroplasts and intracellular membranes. This aids it in siphoning nutrients from the host plant, thereby interfering with photosynthesis and plant development. In response to feeding damage, infested leaves curl lengthwise and develop white or yellowish longitudinal streaks; under colder conditions, these streaks may turn purple. Plants can be infested at any stage from emergence through maturity; infestations during early growth cause the most serious damage. In addition, Russian wheat aphid can cause indirect damage by transmitting plant pathogens such as barley yellow dwarf and other viruses.

\section{Sampling program}

During April 1989, wheat fields in El Centro, Lancaster, Lucerne Valley, Riverside and Mexicali (Mexico) were sampled for the presence of natural enemies of Russian wheat aphid. In addition, during 1989, parasitized aphids were sent to us by collaborators in Parlier and Manteca. Sampling continued in 1990 for 3 months, beginning in late March, at the same localities except Lancaster. During April and May 1991, we continued sampling wheat fields at
El Centro and Santa Ynez. During April 1992, only wheat fields at El Centro were sampled.

We collected aphid mummies (dead parasitized aphids from which the adult parasite emerges) from at least two fields at each locality on each date. The number of aphid mummies collected depended on their abundance in the field sampled. Aphid mummies were collected from wheat plants with a small brush or with small scissors used to cut the leaf portion, together with the mummy, and placed inside half-pint waxed-paper containers. Predators were removed from the aphid colonies with a small brush and placed inside vials containing $70 \%$ ethanol. The predators and aphid mummies were then taken to the Riverside laboratory for sorting and identification.

Aphid mummies were placed individually inside gelatin capsules and were kept in the laboratory at room temperature until the emergence of the adult parasite. During 1990-1992, mummies and emerged parasites were counted to determine the relative abundance of the parasite species found. Parasite species were counted only as "present" or "absent" in the wheat fields during 1989, and no attempt was made to determine their relative abundance. Predator species were counted only as "present" or "absent" during the four seasons of our survey.

Despite our efforts to collect only Russian wheat aphid mummies in the field, a number of mummies of other aphid species were detected in the laboratory. However, only parasites emerging from Russian wheat aphid mummies were identified and counted. Thus, our findings pertain only to parasites and predators of this species. Parasites and predators that could not be identified in our laboratory were sent for identification to experts at other laboratories.

\section{Natural enemies}

Natural enemy complex. Our collections during 1989-1992 yielded more than 4,500 Russian wheat aphid mummies and an undetermined number of predators from all the localities sampled. Among the natural enemies found were: (1) three species of Aphidiidae ( $\mathrm{Hy}$ menoptera), Diaeretiella rapae McIntosh, Lysiphlebus testaceipes (Cresson) and Aphidius sp.; (2) one species of Aphelinidae (Hymenoptera), Aphelinus asychis Walker; (3) three species of Syrphidae (Diptera), Allograpta exotica (Wiedemann), Allograpta sp. and Toxomerus marginatus (Say); (4) five species of Coccinellidae (Coleoptera), Hippodamia convergens Guérin-Méneville, Hippodamia quinque- 
signata ambigua LeConte, Coccinella californica Mann., Coccinella novemnotata franciscana Crotch and Scymnus (Pullus) loewii Mulsant, and (5) one species of Chrysopidae (Neuroptera), Chrysoperla carnea (Stephens). In addition, we found three species of hyperparasites (parasites of parasites) from three families of $\mathrm{Hy}$ menoptera: (1) Alloxysta megourae (Ashmead) (Charipidae), (2) Syrphophagus sp. prob. aphidivorus (Mayr) (Encyrtidae) and (3) Pachyneuron sp. (Pteromalidae). The natural enemy and hyperparasite species found at each locality surveyed are given in table 1.

The diversity of predator species was similar at all locations surveyed (table 1). The species found are generalist predators and so may exploit Russian wheat aphid only as its populations increase and other prey become less available. This hypothesis was partially borne out in field observations. We observed that predators were more commonly associated with host crop areas heavily infested with Russian wheat aphid. Therefore, we believe that predators may not be effectively maintaining Russian wheat aphid populations at low levels.

Relative abundance of parasites. As indicated, two families of parasites, Aphidiidae and Aphelinidae, were found to attack Russian wheat aphid in the field at most localities surveyed. Mummies belonging to these families can be distinguished before emergence of the adult parasite. Aphidiid parasites produce tan or light-brown mummies; aphelinid parasites produce black mummies. This difference in color was used to separate mummies from both families and was especially useful in determining the parasite family to which the mummy belonged when no adults emerged or hyperparasites emerged from the aphid mummies. Thus, based on mummy counts, we were able to determine the relative abundance of both parasite families and the incidence of hyperparasitism in each of those families on Russian wheat aphid. Following, we summarize our findings at each locality surveyed.

\section{Findings from five regions}

El Centro. More than 2,700 mummies were collected from several cereal fields during the 1989-1992 cereal-growing seasons at El Centro (table 2). Only aphidiid mummies were collected during 1989. During 1990, both aphidiid and aphelinid mummies were collected; overall, aphidiid mummies were more abundant than aphelinid mummies. During 1990, aphidiid mummies accounted for more than $70 \%$ of the mummies collected on each date, except on
May 1 (52\%). However, aphidiid mummies were found to be more frequently hyperparasitized than aphelinids, except on May 14. Nonetheless, levels of hyperparasitism may be considered high for both parasite families. For example, $94 \%$ of the aphidiid mummies collected May 2 yielded hyperparasites. During 1991, only aphidiid mummies were collected in our samples. Hyperparasitism was lower in our 1991 samples than in our 1990 samples but may still be considered high, except early in the season (April 6). During 1992, except for three aphelinid mummies, our samples contained only aphidiid specimens. Hyperparasitism was also high during 1992, reaching about $50 \%$ on our last sample date (April 25).

The number of parasite and hyperparasite species found attacking Russian wheat aphid varied during the 4 years studied. During 1989, only L. testaceipes was found to parasitize Russian wheat aphid. During 1990, we found $D$. rapae and $A$. asychis in addition to L. testaceipes. During 1991, Aphidius sp. was added to the known natural enemy guild of Russian wheat aphid, but $A$. asychis was not found that year. Finally, during 1992, D. rapae, $L$. testaceipes and A. asychis, but not Aphidius sp., were found parasitizing the aphid. These discrepancies may be due to deficiencies in sampling. However, another factor may contribute to these discrepancies. Since Russian wheat aphid is a new addition to the aphid fauna of the El Centro area, acquired parasite species (especially $A$. asychis and Aphidius sp.) may attack it only as their preferred hosts become less available.

Lucerne Valley. More than 630 mummies were collected from several Lucerne Valley cereal fields during the 1989 and 1990 growing seasons (table 3). Except for two aphelinid mummies collected during 1990, all mummies collected during 1989 and 1990 were aphidiid. The two aphelinid mummies collected yielded each $A$. asychis parasites. The aphidiid mummies yielded mostly $D$. rapae; however, $L$. testaceipes and hyperparasites were also recovered.

\begin{tabular}{|c|c|c|c|}
\hline $\begin{array}{l}\text { Locality } \\
\text { (years sampled) }\end{array}$ & Parasites & Hyperparasites & Predators \\
\hline $\begin{array}{l}\text { El Centro } \\
(1989-1992)\end{array}$ & $\begin{array}{l}\text { Aphidius sp. } \\
\text { Diaeretiella rapae } \\
\text { Lysiphlebus testaceipes } \\
\text { Aphelinus asychis }\end{array}$ & $\begin{array}{l}\text { Alloxysta megourae } \\
\text { Syrphophagus sp. } \\
\text { Pachyneuron sp. }\end{array}$ & $\begin{array}{l}\text { Allograpta sp. } \\
\text { A. exotica } \\
\text { Toxomerus marginata } \\
\text { Hippodamia convergens } \\
\text { Coccinella californica } \\
\text { Scymnus loewii } \\
\text { Chrysoperla carnea }\end{array}$ \\
\hline $\begin{array}{l}\text { Lancaster } \\
\text { (1989) }\end{array}$ & $\begin{array}{l}\text { D. rapae } \\
\text { L. testaceipes }\end{array}$ & Not surveyed & $\begin{array}{l}\text { Same as El Centro except: } \\
\text { S. loewii }\end{array}$ \\
\hline $\begin{array}{l}\text { Lucerne Valley } \\
(1989-1990)\end{array}$ & $\begin{array}{l}\text { D. rapae } \\
\text { L. testaceipes } \\
\text { A. asychis }\end{array}$ & Same as El Centro & $\begin{array}{l}\text { Same as El Centro except: } \\
\text { S. loewii } \\
\text { plus: } \\
\text { Hippodamia quinquesignata ambigua }\end{array}$ \\
\hline $\begin{array}{l}\text { Manteca* } \\
(1989)\end{array}$ & D. rapae & Not surveyed & Not surveyed \\
\hline $\begin{array}{l}\text { Mexicali Valley } \\
(1989-1990)\end{array}$ & $\begin{array}{l}\text { D. rapae } \\
\text { L. testaceipes } \\
\text { A. asychis }\end{array}$ & $\begin{array}{l}\text { A. megourae } \\
\text { Syrphophagus sp. }\end{array}$ & Same as El Centro \\
\hline $\begin{array}{l}\text { Parlier* } \\
(1989)\end{array}$ & $\begin{array}{l}\text { D. rapae } \\
\text { L. testaceipes }\end{array}$ & Not surveyed & Not surveyed \\
\hline $\begin{array}{l}\text { Riverside } \\
(1989-1990)\end{array}$ & Same as El Centro & $\begin{array}{l}\text { A. megourae } \\
\text { Pachyneuron sp. }\end{array}$ & $\begin{array}{l}\text { Same as El Centro except: } \\
\text { S. loewii } \\
\text { plus: } \\
\text { H. quinquesignata ambigua } \\
\text { Coccinella novemnotata franciscana }\end{array}$ \\
\hline $\begin{array}{l}\text { Santa Ynez } \\
(1991)\end{array}$ & $\begin{array}{l}\text { D. rapae } \\
\text { L. testaceipes } \\
\text { A. asychis }\end{array}$ & $\begin{array}{l}\text { A. megourae } \\
\text { Pachyneuron sp. }\end{array}$ & Not surveyed \\
\hline
\end{tabular}


Hyperparasitism levels were lower than those observed at El Centro and only exceeded $20 \%$ in our April 5 sample. Similarly to what we observed at El Centro, the parasite guild of Russian wheat aphid varied between the 2 years sampled.

Mexicali. We collected more than 220 mummies during the 1989 and 1990 cereal-growing seasons at Mexicali (table 4). Only aphidiid mummies were collected during 1989, which yielded $L$. testaceipes parasites only. During 1990, mummies of both Aphidiidae and Aphelinidae were collected at Mexicali. Emergence of parasites from the mummies collected in 1990 was poor. We recovered only one each of $D$. rapae and $L$. testaceipes, in addition to hyperparasites, from the aphidiid mummies collected. Emergence from the aphelinid mummies collected was greater than in the case of the aphidiids. We recovered only $A$. asychis and hyperparasites from the aphelinid mummies.

In contrast to our collections from $\mathrm{El}$ Centro, a few miles away, aphelinid mummies were more common than aphidiid mummies in our 1990 collections from Mexicali. Levels of aphelinid mummies ranged from $59 \%$ in our April 30 sample to $91 \%$ in our May 2 sample. Levels of hyperparasitism in the aphelinid mummies ranged from $18 \%$ to $50 \%$ in our May 1 and April 26 samples, respectively. Our collections suggest that levels of hyperparasitism in the aphidiid mummies are high. However, hyperparasitism was only detectable in our April 26 and April 30 samples because of the generally poor emergence from mummies. No parasites or hyperparasites emerged from aphidiid mummies collected May 1 or from any mummies collected May 2. As in the collections made at El Centro and Lucerne Valley, the parasite guild of Russian wheat aphid varied between the years studied.

Riverside. A total exceeding 630 mummies was collected in different cereal fields at Riverside during 1989, and 1990 (table 5). Only aphidiid mummies were collected during 1989, and these yielded only D. rapae parasites. Mummies collected during 1990 yielded

TABLE 2. Percent relative abundance of parasites and hyperparasites of Russian wheat aphid at El Centro, 1990-1992*

\begin{tabular}{|c|c|c|c|c|c|c|c|c|c|c|c|c|c|c|c|}
\hline \multirow[b]{2}{*}{ Date } & \multicolumn{8}{|c|}{ Aphidiid mummies } & \multicolumn{6}{|c|}{ Aphelinid mummies } & \multirow[b]{2}{*}{$\Sigma$} \\
\hline & D.r. ${ }^{\dagger}$ & L.t. & A.s. & A.m. & P.s. & S.s. & $\mathrm{N}$ & & A.a. & A.m. & P.s. & S.s. & & N & \\
\hline & \multicolumn{15}{|c|}{1990} \\
\hline $4 / 5$ & 5.0 & 8.6 & 0 & 47.3 & 36.9 & 2.2 & 806 & (279) & - & - & - & - & 0 & $(0)$ & 806 \\
\hline $4 / 12$ & 30.8 & 7.7 & 0 & 34.6 & 26.9 & 0 & 85 & $(26)$ & 92.3 & 7.7 & 0 & 0 & 23 & (13) & 108 \\
\hline $4 / 18$ & 29.2 & 8.3 & 0 & 41.7 & 16.6 & 4.2 & 95 & (24) & 25.0 & 12.5 & 31.3 & 31.3 & 35 & (16) & 130 \\
\hline $4 / 25$ & 5.9 & 2.9 & 0 & 52.9 & 26.5 & 11.8 & 87 & (34) & 75.0 & 0 & 12.5 & 12.5 & 27 & (8) & 114 \\
\hline $5 / 1$ & 14.3 & 0 & 0 & 71.4 & 0 & 14.3 & 80 & (14) & 58.1 & 25.8 & 6.4 & 9.7 & 73 & (31) & 153 \\
\hline $5 / 2$ & 5.6 & 0 & 0 & 11.1 & 80.6 & 2.7 & 67 & (36) & 81.8 & 0 & 9.1 & 9.1 & 19 & (11) & 86 \\
\hline $5 / 7$ & 15.5 & 0 & 0 & 15.5 & 64.4 & 4.5 & 109 & (45) & 33.3 & 0 & 33.3 & 33.3 & 6 & (3) & 115 \\
\hline \multirow[t]{2}{*}{$5 / 14$} & 78.9 & 0 & 0 & 8.8 & 7.0 & 5.3 & 160 & $(57)$ & 100.0 & 0 & 0 & 0 & 1 & (1) & 161 \\
\hline & \multicolumn{15}{|c|}{1991} \\
\hline $4 / 6$ & 53.7 & 36.8 & 0 & 9.5 & 0 & 0 & 295 & (136) & - & - & - & - & 0 & (0) & 295 \\
\hline $4 / 13$ & 65.2 & 15.1 & 0 & 15.1 & 0 & 4.6 & 165 & (66) & - & - & - & - & 0 & (0) & 165 \\
\hline $4 / 20$ & 55.6 & 44.4 & 0 & 0 & 0 & 0 & 159 & (18) & - & - & - & - & 0 & (0) & 159 \\
\hline $4 / 27$ & 30.0 & 35.0 & 0 & 35.0 & 0 & 0 & 101 & (20) & - & - & - & - & 0 & (0) & 101 \\
\hline $5 / 3$ & 34.6 & 0 & 0 & 42.3 & 0 & 23.1 & 71 & (26) & - & - & - & - & 0 & (0) & 71 \\
\hline \multirow[t]{2}{*}{$5 / 11$} & 59.1 & 0 & 4.5 & 9.1 & 0 & 27.3 & 47 & (22) & - & - & - & - & 0 & (0) & 47 \\
\hline & \multicolumn{15}{|c|}{1992} \\
\hline $4 / 4$ & 50.0 & 3.6 & 0 & 42.9 & 3.6 & 3.6 & 148 & (56) & 100.0 & 0 & 0 & 0 & 1 & (1) & 149 \\
\hline $4 / 13$ & 20.0 & 40.0 & 0 & 40.0 & 0 & 0 & 17 & (5) & - & - & - & - & 0 & (0) & 17 \\
\hline $4 / 18$ & 50.0 & 20.0 & 0 & 20.0 & 0 & 10.0 & 26 & (10) & 100.0 & 0 & 0 & 0 & 2 & (2) & 28 \\
\hline $4 / 25$ & 40.0 & 10.0 & 0 & 50.0 & 0 & 0 & 29 & (10) & - & - & - & - & 0 & (0) & 29 \\
\hline
\end{tabular}

*Percentage figures are based on numbers of parasites and hyperparasites emerged from mummies collected on each date.

†D.r. $=$ D. rapae, L.t. $=$ L. testaceipes, A.s. $=$ Aphidius sp., A.m. $=$ A. megourae, P.s. $=$ Pachyneuron sp. S.s. = Syrphophagus sp., $\mathrm{N}=$ number of aphidiid or aphelinid mummies collected on each date, followed by number of parasites or hyperparasites emerging from mummies (in parentheses), $\Sigma=$ total number of mummies collected on each date.

Aphidius sp. and A. asychis, in addition to $D$. rapae. Aphelinid mummies were collected that year only on June 22, when they were more numerous than aphidiids. Levels of hyperparasitism in the Aphidiidae ranged from $2 \%$ in our first sample, April 17, to $73 \%$ on April 27. However, in general, levels of hyperparasitism at Riverside were lower than at El Centro. Our collections at Riverside during 1989 and 1990 again suggest a variable parasite guild for Russian wheat aphid.

Santa Ynez. Conditions at Santa Ynez during 1991 were relatively poor during the first sampling dates (aphid numbers and hence aphid mummies were low, except late in the season). However, more than 350 mummies were collected overall during the 1991 cerealgrowing season (table 6). Both aphidiid and aphelinid mummies were collected, the former being the most common. Three species of parasites, D. rapae, $L$. testaceipes and $A$. asychis, and two hyperparasite species were recovered. Levels of hyperparasitism appeared lower than at other localities sampled. The number of parasites, or hyperparasites, emerging from the mummies collected at Santa Ynez, was exceptionally low. Overall, emergence of parasites and hyperparasites from our samples was $10 \%$.

\section{Conclusions}

The natural enemy guild of the Russian wheat aphid, that is the group of natural enemies attacking this pest, at the localities studied is comprised of at least four parasite and nine predator species (table 1). At all localities studied $D$. rapae was the most common parasite, except at Mexicali, where $A$. asychis was more common. However, at localities where $A$. asychis was collected, its abundance generally increased in the later samples. This may indicate that $A$. asychis prefers other aphid hosts early in the season and parasitizes Russian wheat aphid only when preferred hosts are less available. Also, available data suggest that $A$. asychis populations may appear in the field and build up later than aphidiid populations. We believe that the $A$. asychis we collected may have originated from colonizations of this species in California, beginning in 1955, for biological control of the spotted alfalfa aphid (at the time referred to as Aphelinus semiflavus Howard).

It appears that upon its establishment, Russian wheat aphid has acquired new polyphagous parasite species. These polyphagous parasites, especially Aphidius sp. and A. asychis, may be considered "opportunist" species in the case of Russian wheat aphid, parasitizing it 
only when preferred hosts are less available. The composition of the parasite guild varied at locations for which multi-year data are available.

Although a number of natural enemy species attack Russian wheat aphid in California, these may not significantly impact its population levels. Past experience shows that a certain degree of host specificity is a common attribute of effective natural enemies. The natural enemies of Russian wheat aphid in California are not host-specific. On the one hand, we have a complex of predators, all generalists, that attack prey species from several families of insects, or at best, attack many species from the aphid family. On the other hand, we have a

TABLE 3. Percent relative abundance of parasites and hyperparasites of Russian wheat aphid at Lucerne Valley during $1990^{*}$

\begin{tabular}{|c|c|c|c|c|c|c|c|c|c|c|}
\hline \multirow[b]{2}{*}{ Date } & \multicolumn{7}{|c|}{ Aphidiid mummies } & \multicolumn{2}{|c|}{$\begin{array}{l}\text { Aphelinid } \\
\text { mummies }\end{array}$} & \multirow[b]{2}{*}{$\Sigma$} \\
\hline & D.r. ${ }^{\dagger}$ & L.t. & A.m. & P.s. & S.s. & & $\mathrm{N}$ & A.a. & $\mathrm{N}$ & \\
\hline $3 / 29$ & 87.5 & 8.7 & 2.9 & 0 & 0.9 & 220 & $(104)$ & - & $0(0)$ & 220 \\
\hline $4 / 5$ & 69.2 & 7.7 & 5.1 & 17.9 & 0 & 100 & (39) & - & $0(0)$ & 100 \\
\hline $4 / 13$ & 79.7 & 6.8 & 5.4 & 8.1 & 0 & 139 & (74) & 100.0 & $1(1)$ & 140 \\
\hline $4 / 23$ & 74.1 & 11.1 & 0 & 13.0 & 1.9 & 136 & (54) & - & $0(0)$ & 136 \\
\hline $5 / 10$ & 100.0 & 0 & 0 & 0 & 0 & 40 & (18) & 100.0 & $1(1)$ & 41 \\
\hline
\end{tabular}

*Percentage figures are based on numbers of parasites and hyperparasites emerged from mummies on each date.

tSee table 2 for explanation of abbreviations and symbols used.

TABLE 4. Percent relative abundance of parasites and hyperparasites of Russian wheat aphid at Mexicali, Mexico, $1990^{*}$

\begin{tabular}{|c|c|c|c|c|c|c|c|c|c|c|}
\hline \multirow[b]{2}{*}{ Date } & \multicolumn{5}{|c|}{ Aphidiid mummies } & \multicolumn{4}{|c|}{ Aphelinid mummies } & \multirow[b]{2}{*}{$\Sigma$} \\
\hline & D.r. ${ }^{\dagger}$ & L.t. & A.m. & S.s. & $\mathrm{N}$ & A.a. & A.m. & S.s. & $\mathrm{N}$ & \\
\hline $4 / 26$ & 11.1 & 0 & 66.7 & 22.2 & $12(9)$ & 50.0 & 31.3 & 18.7 & $54(16)$ & 66 \\
\hline $4 / 30$ & 0 & 16.7 & 66.6 & 16.7 & 30 (6) & 80.0 & 10.0 & 10.0 & $29(10)$ & 49 \\
\hline $5 / 1$ & 0 & 0 & 0 & 0 & $5(0)$ & 81.8 & 9.1 & 9.1 & $48(11)$ & 53 \\
\hline $5 / 2$ & 0 & 0 & 0 & 0 & $5(0)$ & 0 & 0 & 0 & $50(0)$ & 55 \\
\hline
\end{tabular}

*Percentage figures are based on numbers of parasites and hyperparasites emerged from mummies collected on each date.

† See table 2 for explanation of abbreviations and symbols used.

TABLE 5. Percent relative abundance of parasites and hyperparasites of Russian wheat aphid at Riverside, $1990^{*}$

\begin{tabular}{|c|c|c|c|c|c|c|c|c|c|c|}
\hline \multirow[b]{2}{*}{ Date } & \multicolumn{6}{|c|}{ Aphidiid mummies } & \multicolumn{3}{|c|}{ Aphelinid mummies } & \multirow[b]{2}{*}{$\Sigma$} \\
\hline & D.r. ${ }^{\dagger}$ & L.t. & A.s. & A.m. & P.s. & $\mathrm{N}$ & A.a. & A.m. & $\mathrm{N}$ & \\
\hline $4 / 17$ & 87.8 & 7.3 & 2.4 & 2.4 & 0 & $80 \quad(41)$ & - & - & $0(0)$ & 80 \\
\hline $4 / 23$ & 51.7 & 2.5 & 0.8 & 15.8 & 29.2 & 200 (120) & - & - & $0(0)$ & 200 \\
\hline $4 / 27$ & 24.7 & 2.2 & 0 & 11.8 & 61.3 & 150 (93) & - & - & $0(0)$ & 150 \\
\hline $5 / 2$ & 45.0 & 3.0 & 0 & 14.0 & 38.0 & $150(100)$ & - & - & $0(0)$ & 150 \\
\hline $6 / 22$ & 66.6 & 0 & 0 & 16.7 & 16.7 & $17 \quad(6)$ & 88.9 & 11.1 & 34 (18) & 51 \\
\hline
\end{tabular}

*Percentage figures are based on numbers of parasites and hyperparasites emerged from mummies collected on each date.

tSee table 2 for explanation of abbreviations and symbols used.

TABLE 6. Relative abundance of parasites and hyperparasites of Russian wheat aphid at Santa Ynez during $1991^{\star}$

\begin{tabular}{|c|c|c|c|c|c|c|c|c|}
\hline \multirow[b]{2}{*}{ Date } & \multicolumn{4}{|c|}{ Aphidiid mummies } & \multicolumn{3}{|c|}{ Aphelinid mummies } & \multirow[b]{2}{*}{$\Sigma$} \\
\hline & D.r. ${ }^{\dagger}$ & L.t. & P.s. & N & A.a. & A.m. & N & \\
\hline $4 / 24$ & 100.0 & 0 & 0 & 17 (2) & 50.0 & 50.0 & 2 (2) & 19 \\
\hline $5 / 2$ & 40.0 & 60.0 & 0 & $26(10)$ & - & - & $0 \quad(0)$ & 26 \\
\hline $5 / 4$ & 87.5 & 0 & 12.5 & $50(16)$ & - & - & $0 \quad(0)$ & 50 \\
\hline $5 / 10$ & 100.0 & 0 & 0 & 269 (4) & 100.0 & 0 & 6 (2) & 275 \\
\hline
\end{tabular}

-Percentage figures are based on numbers of parasites and hyperparasites emerged from mummies collected on each date.

†See table 2 for explanation of abbreviations and symbols used.

small number of parasites with an extended host range. For example, there are at least 32 known hosts of $L$. testaceipes and eight of $D$. rapae in California. Another factor that may contribute to the ineffectiveness of the parasites in maintaining Russian wheat aphid populations at low levels is the high level of hyperparasitism observed in our samples. Furthermore, the habit of Russian wheat aphid colonies of living inside curled leaves may afford them protection from natural enemies not adapted to searching in such concealed niches.

The impact of the extant natural enemies on Russian wheat aphid populations may be augmented by introducing natural enemies more specific and better adapted to its biology. Published records, together with recent findings, reveal that effective natural enemies of this pest exist where it has long been present at low levels. These areas should be explored, and the natural enemies of Russian wheat aphid found, imported to and colonized in California. Because of environmental and economic considerations, management of Russian wheat aphid in California should not rely mainly on using insecticides. Biological control, coupled with plant resistance, may be a more judicious approach toward managing this pest in California.

Many natural enemies of Russian wheat aphid have been imported through university and federal efforts and are now being reared at insectaries in the western United States, including the insectary at Riverside. Imported natural enemies may provide permanent, self-sustaining and economical control of Russian wheat aphid in California and should be exploited.

J. Bernal, D. González and J. G. Loya are Graduate Student, Entomologist and Visiting Researcher, respectively, Department of Entomology, UC Riverside; E. T. Natwick and W. E. Bendixen are Farm Advisors, UC Cooperative Extension at Imperial and Santa Barbara counties, respectively; $R$. León-Lopez is with Instituto Nacional de Investigaciones Forestales Agricolas y Pecuarias, Mexicali, México.

We are grateful to P. Stary (Czechoslovak Academy of Sciences), P. Marsh (U.S. Department of Agriculture/Systematic Entomology Laboratory or USDA/SEL) and $M$. Schauff (USDA/SEL) for assistance with parasite and hyperparasite identifications, K. S. Hagen (UC Berkeley) for assistance with Coccinellidae identifications and F.C. Thompson (USDA/SEL) for assistance with identification of Syrphidae. M. L. Flint, C. Summers and J. R. Quezada assisted with collections from Manteca and Parlier. 